\title{
慢性期頭蓋内血管狭窄症に対する最良の治療選択
}

\author{
吉村 紳一, 内田 和孝, 山田 清文, 高木 俊範, 白川 学 \\ 兵庫医科大学脳神経外科学講座
}

\section{Best Treatment Selection for Chronic Intracranial Artery Stenosis}

\author{
Shinichi Yoshimura, M.D., Kazutaka Uchida, M.D., Kiyofumi Yamada, M.D., Toshinori Takagi, M.D., and \\ Manabu Shirakawa, M.D.
}

Department of Neurosurgery, Hyogo College of Medicine

Purpose: Clinical trials did not show the efficacy of endovascular therapy or open surgery for symptomatic intracranial artery stenosis (ICAS). However, the number of the patients resistant or contraindicated for medical therapy is not small, and there is no consensus how to treat such patients. In this report, clinical evidences regarding ICAS treatment were reviewed and treatment selection was discussed.

Background: ICAS accounts for 30\% of total cerebral infarction approximately. The recurrence rate of stroke in patients having severe stenosis $(>70 \%)$ was reported to be around $23 \%$ during aspirin treatment and around $12 \%$ during aggressive medical therapy including antiplatelets, blood pressure control, lipid lowering, and life style modification such as smoking cessation.

Treatments and clinical evidences: 1) Medical therapy: Randomized controlled trial (RCT) showed that aspirin was superior to warfarin. 2) Two RCTs failed to show the efficacy of endovascular therapy for symptomatic ICAS. Therefore, aggressive medical treatment is regarded as the first option. On the other hand, a new RCT in China is ongoing based on the previous studies. 3) Bypass surgery: There is no RCT aiming to show the efficacy of bypass surgery for ICAS. However, bypass is sometimes performed for the patients who are resistant or contraindicated for other therapies.

Conclusions: The standard treatment is medical therapy according to the clinical trials, however the efficacy of endovascular or other therapies for the medically-refractory patients will be tested in clinical trials.

(Received November 13, 2018; accepted November 29, 2018)

Key words : intracranial artery stenosis, medical therapy, bypass, endovascular treatment, stenting Jpn J Neurosurg（Tokyo）28:783-788, 2019

\section{はじめに}

頭蓋内動脈狭窄症（intracranial artery stenosis：ICAS） はわれわれ日本人に多い疾患であり，わが国の全脳梗塞 の原因の約 $1 / 3$ を占めるとされることから，その適切な 治療法を知ることは重要である。しかしながら, 頝動脈
狭窄症と違い ICAS に対する外科手術や血管内手術の有 効性は確立していないため, 内科的治療が第 1 選択と なっている。一方，内科的治療に対する抵抗例・非適応 例も比較的多く，このような症例をどう治療するかにつ いては一定の見解がない，本稿ではICASに関する現時 点での情報を概観し，治療法選択について考察する.

連絡先：吉村紳一，干 663-8501 西宮市武庫川町 1-1 兵庫医科大学脳神経外科学講座

Address reprint requests to : Shinichi Yoshimura, M.D., Department of Neurosurgery, Hyogo College of Medicine, 1-1

Mukogawa, Nishinomiya-shi, Hyogo 663-8501, Japan 

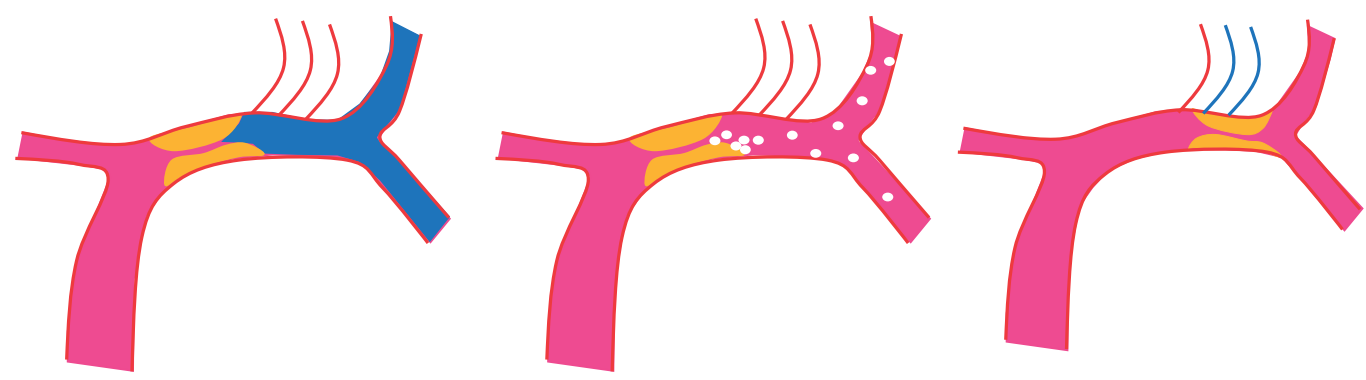

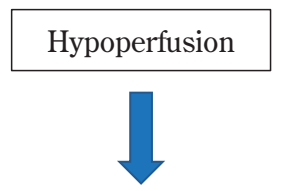

Angioplasty Bypass

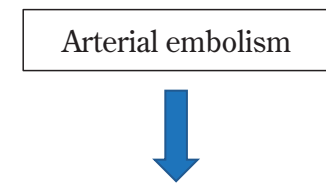

Medication Angioplasty

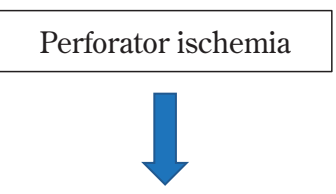

Medication

Fig. 1 Schematic drawing of stroke types of intracranial artery and possible therapies

\section{疫学・自然歴}

ICAS はアジア人においては全脳梗塞の原因の約 30〜 $50 \%$ 占めるとされており, 白人に頭蓋外動脈狭窄が多 いのとは対照的である ${ }^{810)}$. 好発部位は, 内頝動脈サイ フォン部，中大脳動脈，脳底動脈で，高度狭窄（70\%以 上）と直近の再発作が再発のリスク因子であると報告さ れている ${ }^{11)}$. 最近, もやもや病患者の約 $80 \%$ に認められ る RNF213 遺伝子変異が近位 ICAS 患者の 20 25\%にお いても認められることが報告されており, ICASがアジ ア人に多いことからも大変興味深い1)14).

ICAS の自然歴について，これまでの臨床試験を参考 として考察する。まずアスピリンとワルファリンの治療 成績に関するランダム化比較試験 (randomized controlled trial：RCT）WASID trialにおいて，アスピリン投与下で 中等度狭窄例（狭窄度 50 69\%）では年間 8\%, 高度狭 窄例（70〜99\%）では年間 23\%の脳卒中再発率が示され ている゙）。た，同試験においては収縮期血圧が高值 （140 mmHg 以上）の患者, 総コレステロール值が高值 $(200 \mathrm{mg} / \mathrm{d} l$ 以上）の患者においてはより再発率が高いこ と, 一定以上の重症度〔National Institutes of Health stroke scale（NIHSS） 2 点以上], 発作から短期間（17 日以内） の症例において再発率が高かったことが示された。

\section{虚血発作の病型}

ICAS による虚血症状は，(1)狭窄による脳血流の低下，
(2)狭窄部からの塞栓症，(3)穿通枝閉塞の 3 つによって生 じ得る（Fig. 1)。それぞれに最適な治療は異なり，たと えば(1)に対しては血流を増やす介入治療（バイパス手術 や血管内治療)，(2)対しては抗血栓療法(抗血小板薬), プラークを安定化させる内科的治療 (スタチンなど), 血 管内治療などが有効と考えられる。一方, (3) ICAS 独 特の病型であり, 内科的治療のみが候補となり, バイパ 久手術や血管内治療は無効と考えられるため，診断に注 意が必要である.

\section{各治療法とエビデンス}

脳血管に限らず，動脈狭窄性病変に対しては，内科的 治療，血管内手術，バイパス手術の 3 つの治療法が存在 する，血管が細いために生じる病態であるので，狭窄部 を拡張したり，バイパスで血流を改善すればよいと単純 に考えがちであるが，各治療法で合併症が生じ得ること を考慮に入れなければならない，以下，各治療法につい て解説する.

\section{1 内科的治療}

前述の WASID trial においてはICAS におけるワルファ リンとアスピリンの有効性と安全性が比較された ${ }^{3)}$. 対 象は中等度から高度狭窄（狭窄度 50９9\%）の症候性患 者 569 例で，ワルファリン群は international normalized ratio（INR）2.0〜3.0 が目標とされ，アスピリン群ではア スピリン $1,300 \mathrm{mg} /$ 日が投与された. 結果, 一次エンドポ 
Table 1 Primary and secondary end points in WASID trial (quoted and modified from Ref. 3)

\begin{tabular}{l|c|c|c|c}
\hline \multicolumn{1}{c|}{ Group } & Aspirin & Warfarin & $\begin{array}{c}\text { Hazard ratio } \\
(95 \% \mathrm{CI})\end{array}$ & $\mathrm{p}$ value \\
\hline $\begin{array}{l}\text { Primary and secondary endpoints } \\
\text { Ischemic stroke, brain hemorrhage or death } \\
\text { from other vascular causes }\end{array}$ & $22.1 \%$ & $21.8 \%$ & $\begin{array}{c}1.04 \\
(0.73-1.48) \\
0.98\end{array}$ & 0.83 \\
$\quad \begin{array}{l}\text { Ischemic stroke in territory of stenotic artery } \\
(0.70-1.37)\end{array}$ & $15.0 \%$ & $12.1 \%$ & 0.31 \\
\hline $\begin{array}{l}\text { Adverse events } \\
\text { Death }\end{array}$ & $4.3 \%$ & $9.7 \%$ & $\begin{array}{c}0.46 \\
(0.23-0.90) \\
0.39\end{array}$ & 0.02 \\
Major hemorrhage & $3.2 \%$ & $8.3 \%$ & $\begin{array}{c}0.18-0.84) \\
(0.18\end{array}$ & \\
\hline
\end{tabular}

Table 2 Comparison of treatment groups in SAMMPRIS trial (quoted from Ref. 6)

\begin{tabular}{l|r|r|l}
\hline \multicolumn{1}{c|}{ Outcome } & $\begin{array}{c}\text { Medical group } \\
(\mathrm{n}=227)\end{array}$ & $\begin{array}{c}\text { Stent group } \\
(\mathrm{n}=224)\end{array}$ & $\mathrm{p}$ value \\
\hline Primary endpoint & $34(15 \%)$ & $52(23 \%)$ & 0.0252 \\
Any stroke or death & $51(23 \%)$ & $64(29 \%)$ & 0.13 \\
Any death & $13(6 \%)$ & $13(6 \%)$ & 0.90 \\
Any stroke & $42(19 \%)$ & $59(26 \%)$ & 0.0468 \\
Disabling or fatal stroke & $18(8 \%)$ & $21(9 \%)$ & 0.51 \\
Myocardial infarction & $9(4 \%)$ & $5(2 \%)$ & 0.34 \\
Major non-stroke hemorrhage & $9(4 \%)$ & $16(7 \%)$ & 0.11 \\
Any major hemorrhage & $10(4 \%)$ & $29(13 \%)$ & 0.0009 \\
\hline
\end{tabular}

イント（虚血性脳卒中，脳出血，他の血管死）および二 次エンドポイント（支配血管領域の虚血発作）において は両群に有意差を認めなかったが，ワルファリン群にお いては死亡と重度出血が有意に多かった (Table 1). 以上 から，症候性 ICAS においてはアスピリンが優位である ことが示された。

ただし近年，心原性脳塞栓症に対する新たな抗凝固薬 (direct oral anticoagulant：DOAC) が市販され，広く使用 されるようになった。本薬はワルファリンと同等または それ以上の虚血イベント抑制効果を有し，頭蓋内出血を 含む重度出血合併症が少ないことが報告されてい る477)916)。したがって, 症候性 ICAS 患者におけるアス ピリンとDOAC の比較試験が行われた場合，どのような 結果となるかは大変興味深い.

\section{2 血管内治療}

わが国においても ICAS に対する血管形成術，Wingspan stent は血管形成時の血管解離や急性閉塞 - 切迫閉

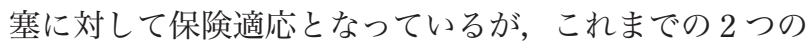

RCT において血管内治療の有効性は示されていない，以 下に詳細を示す。

\section{SAMMPRIS 試験}

頭蓋内ステント留置術に関する初めてのRCTで, わが 国で使用されている自己拡張型の Wingspan stent が使用 された ${ }^{2) 6}$ ）積極的内科治療（抗血小板療法, 降圧療法, 脂質低下療法，禁煙などの生活習慣改善）とステント留 置術の治療成績が比較された。症候性高度狭窄（70～ 99\%)を有する患者が発症 30 日以内に登録された。しか し中間解析の段階で血管内治療群の合併症率が高かった ため, 安全性の懸念から割り付けは計 451 例で中止され $た^{2)}$. 最終解析における 1 年間の一次エンドポイント (登 録から 30 日以内の脳卒中と死亡，30日以降の当該血管 領域の脳梗塞，治療から 30 日以内の脳卒中と死亡）も血 管内治療群（224 例）で $23 \%$ ，内科治療群 (227 例) で $15 \%$ と，血管内治療群で有意に不良であった（ $0.0252{ }^{6)}$ (Table 2)。また， 2 年間の一次エンドポイント も血管内治療群 $20.6 \%$ ，内科治療群 $14.1 \%$ と，血管内治 療群で有意に不良であった $(\mathrm{p}=0.002)$ ，以上から症候性 
Table 3 30-day and 1-year end points in VISSIT trial (quoted and modified from Ref. 18)

\begin{tabular}{|c|c|c|c|c|}
\hline Outcome & $\begin{array}{l}\text { Medical group } \\
\quad(\mathrm{n}=53)\end{array}$ & $\begin{array}{l}\text { Stent group } \\
\quad(n=58)\end{array}$ & $\begin{array}{l}\text { Hazard ratio } \\
(95 \% \mathrm{CI})\end{array}$ & $\mathrm{p}$ value \\
\hline \multirow{3}{*}{$\begin{array}{l}\text { Primary effective end points } \\
\text { Stroke in the same territory within } 1 \text { year or hard } \\
\text { TIA in the same territory between } 2 \text { day and } 1 \text { year } \\
\text { Stroke in the same territory within } 1 \text { year }\end{array}$} & & & & \\
\hline & $8 / 53(15.1 \%)$ & $21 / 58(36.2 \%)$ & $\begin{array}{c}21.1 \\
(54-36.8)\end{array}$ & 0.02 \\
\hline & $5 / 53(9.4 \%)$ & $20 / 58(34.5 \%)$ & 25.1 & 0.003 \\
\hline Hard TIA between 2 day and 1 year & $3 / 53(5.7 \%)$ & $1 / 58(1.7 \%)$ & $\begin{array}{c}(10.5-39.6) \\
-3.9 \\
(-11.0 \text { to } 3.1)\end{array}$ & 0.35 \\
\hline \multicolumn{5}{|l|}{ Safety outcomes within 30 day } \\
\hline $\begin{array}{l}\text { Any stroke within } 30 \text { day or hard TIA between } 2 \text { day } \\
\text { and } 30 \text { day }\end{array}$ & $5 / 53(9.4 \%)$ & $14 / 58(24.1 \%)$ & $\begin{array}{c}14.7 \\
(1.2-28.2)\end{array}$ & 0.05 \\
\hline Any ischemic stroke within 30 day & $3 / 53(5.7 \%)$ & $10 / 58(17.2 \%)$ & $\begin{array}{c}11.6 \\
(0-23.1)\end{array}$ & 0.08 \\
\hline Any hard TIA from day 2 through day 30 & $2 / 53(3.8 \%)$ & $0 / 58(0 \%)$ & $\begin{array}{c}-3.8 \\
(-8.9 \text { to } 1.4)\end{array}$ & 0.23 \\
\hline Intracranial hemorrhage within 30 day & $0 / 53(0 \%)$ & $5 / 58(8.6 \%)$ & $\begin{array}{c}8.6 \\
(1.4-15.8) \\
\end{array}$ & 0.06 \\
\hline
\end{tabular}

高度狭窄に対する積極的内科治療の優位性はフォロー アップを延長しても継続することが確認された。

本試験においては血管内治療の周術期合併症が多かっ た原因として, (1)発症後早期の介入 (平均 10 日以内) で あったために虚血・出血性合併症が起きやすい状態で あったこと，(2)ステントが自己拡張型であったこと，な どが推定された。

\section{VISSIT 試験}

ICAS に対するバルーン拡張型ステントの有効性を検 討した RCTである ${ }^{18)}$. 30 日以内に虚血発作をきたした 症候性 ICAS（狭窄度 70 99\%）を内科治療群と血管内 治療群に割り付け解析した。本試験は SAMMPRIS 試験 の否定的な結果を受け，当初の登録予定 250 例のうち 112 例を登録した時点で中止された。その結果，いずれ の項目においてもステント群で不良であった(Table 3).

本試験でも，ICAS に対するステント留置術の有効性 は示されず，積極的内科治療のほうが良好であった。

以上 2 つの RCT で血管内治療の有効性は否定され, 積 極的内科治療が標準治療とみなされている。また，積極 的内科治療を行うことで, WASID の内科的治療群である アスピリンのみの治療と比較すると年間脳卒中・死亡率 は $12 \%$ に減少している。しかし,この再発率は必ずしも 低いとはいえず，実際に再発した場合には治療選択に苦 慮することとなる.

ICAS におけるステント留置術が頝動脈などにおける 治療に比べて成績が不良である主原因は治療による穿通 枝閉塞が多いためと考えられている( ${ }^{617)}$ 。これは血管拡
張によって押しつぶされたプラークが近傍の穿通枝分岐 部に移動することが原因と考えられており, 雪かき効果 (snow plow effect) と呼ばれている。このように, 穿通枝 が狭窄部近傍に存在する場合には血管拡張術のリスクが 高いことに注意しなければならない.また, Mori ら ${ }^{15)}$ ICASを 3 タイプに分け, type A に分類される, 短く（5 $\mathrm{mm}$ 以下), 求心性または中等度までの偏心性病変におい て血管形成術の治療成績が最も良好であることを報告し ている．また血管径が小さい病変は解離による出血合併 症が多く，これも考慮に入れるべきと考えられる.

最近, 中国における ICAS に対する血管内治療の登録 調査の結果が報告された ${ }^{13)}$. 同調査では一次エンドポイ ントは 30 日以内の全脳卒中，TIA，死亡と定義された。 連続 354 例中，基準に合致した症例を解析したところ， バルーン拡張型ステント群（151 例）における一次エン ドポイントは $4.4 \%$, 自己拡張型ステント群（141 例）で は 4.3\%であり，前述の RCT と比べ，より良好な治療成 績であった。その原因として，同国では治療経験が多い こと, 若年患者が多かったこと, 脳卒中よりも TIA が多 かったこと, 最終発作から治療までの期間が長かったこ と，などが想定されている。それ以外にも病変長が短い もの (15 mm 以下), 直径 $2 \mathrm{~mm}$ 以上の血管が対象となっ たことが影響したものと考えられる。

現在，中国では狭窄血管の領域に脳血流低下を有する 症例を対象とした RCT が進行中である ${ }^{5)}$. 脳血流低下を 有する場合には脳卒中再発率が高いことが示されてお り，治療対象としてよい候補と考えられる。また同試験 
ではアスピリン抵抗性で病変長が短く（15 mm 以下 $)$, 血管径が大きく (直径 $2.5 \mathrm{~mm}$ 以上), 発作から 2 週間以 上経過した症例が対象とされている。このように，今後 は血管内治療でより恩恵を受けやすい症例をターゲット とした比較試験が行われていくものと考えられる.

\section{3 外科的治療}

頭蓋外内バイパス手術は狭窄により低下した脳血流を 改善することで再発作を減らすことが可能と考えられる が, 頭蓋内動脈狭窄症のみを対象としたRCTは行われて いない. 最近, 内科的治療抵抗性でステント留置術に適 さないと考えられる症例に対するバイパス手術に関する 報告がなされている ${ }^{12)}$. 連続 185 例中, 内科的治療抵抗 性で, 病変の特徴（病変長，屈曲など）でステント留置 術がハイリスクと判断され，しかも脳血流低下を認めた 15例に対してバイパス手術が行われた。フォローアップ は約 30 カ月で, 全例でバイパスの開存が確認され, 虚血 発作の再発は認めなかった。しかし，4例で狭窄部が閉 塞しており， 2 例が 7 日以内， 1 例が 6 力月後， 1 例が 8 カ月後であった。バイパスの流れが良好な症例ほど早期 の狭窄部閉塞をきたしやすいことが示されている.

閉塞病変におけるバイパス術の有効性が否定されてい ることから，狭窄病変に対する試験が行いにくい状況に あるが，本報告のように内科的治療抵抗例においては選 択肢になり得る可能性がある。

\section{結 語}

症候性 ICAS に関する RCT を中心に, 各治療法の成績 を概観した。本疾患に対しては積極的内科治療が第 1 選 択であるが，禁煙などの生活習慣の改善を含めた本療法 の実施は必ずしも容易ではない。また，治療中に再発作 をきたし外科的介入に踏み切らざるを得ないこともあ る。引き続き本疾患の最良の治療選択を明らかにするた めの臨床試験が期待される。

\section{COI}

著者全員は日本脳神経外科学会への COI 自己申告の登録を 完了しており，筆頭著者が昨年 1 月〜 12 月において本論文に 関して開示すべき COI は下記のとおりです。

吉村紳一：日本ベーリンガーインゲルハイム，第一三共， 日本メドトロニック社より講演料（年間合計 100 万円以上）

\section{文 献}

1) Bang OY, Chung JW, Cha J, Lee MJ, Yeon JY, Ki CS, Jeon P, Kim JS, Hong SC : A polymorphism in RNF213 is a suscep- tibility gene for intracranial atherosclerosis. PLoS One 11: e0156607, 2016.

2) Chimowitz MI, Lynn MJ, Derdeyn CP, Turan TN, Fiorella D, Lane BF, Janis LS, Lutsep HL, Barnwell SL, Waters MF, Hoh BL, Hourihane JM, Levy EI, Alexandrov AV, Harrigan MR, Chiu D, Klucznik RP, Clark JM, McDougall CG, Johnson MD, Pride GL Jr, Torbey MT, Zaidat OO, Rumboldt Z, Cloft HJ ; SAMMPRIS Trial Investigators: Stenting versus aggressive medical therapy for intracranial arterial stenosis. NEngl J Med 365 : 993-1003, 2011.

3) Chimowitz MI, Lynn MJ, Howlett-Smith H, Stern BJ, Hertzberg VS, Frankel MR, Levine SR, Chaturvedi S, Kasner SE, Benesch CG, Sila CA, Jovin TG, Romano JG ; WarfarinAspirin Symptomatic Intracranial Disease Trial Investigators: Comparison of warfarin and aspirin for symptomatic intracranial arterial stenosis. N Engl J Med 352: 13051316, 2005.

4) Connolly SJ, Ezekowitz MD, Yusuf S, Eikelboom J, Oldgren J, Parekh A, Pogue J, Reilly PA, Themeles E, Varrone J, Wang S, Alings M, Xavier D, Zhu J, Diaz R, Lewis BS, Darius H, Diener HC, Joyner CD, Wallentin L ; RE-LY Steering Committee and Investigators: Dabigatran versus warfarin in patients with atrial fibrillation. $N$ Engl J Med 361 : 1139-1151, 2009.

5) Cui XP, Lin M, Mu JS, Ye JX, He WQ, Fu ML, Li H, Fang JY, Shen FF, Lin $\mathrm{H}$ : Angioplasty and stenting for patients with symptomatic intracranial atherosclerosis : study protocol of a randomised controlled trial. BMJ Open $\quad \mathbf{6}: \mathrm{e} 012175$, 2016.

6) Derdeyn CP, Chimowitz MI, Lynn MJ, Fiorella D, Turan TN, Janis LS, Montgomery J, Nizam A, Lane BF, Lutsep HL, Barnwell SL, Waters MF, Hoh BL, Hourihane JM, Levy EI, Alexandrov AV, Harrigan MR, Chiu D, Klucznik RP, Clark JM, McDougall CG, Johnson MD, Pride GL Jr, Lynch JR, Zaidat OO, Rumboldt Z, Cloft HJ ; Stenting and Aggressive Medical Management for Preventing Recurrent Stroke in Intracranial Stenosis Trial Investigators: Aggressive medical treatment with or without stenting in high-risk patients with intracranial artery stenosis (SAMMPRIS) : the final results of a randomised trial. Lancet $383: 333-341,2014$.

7) Giugliano RP, Ruff CT, Braunwald E, Murphy SA, Wiviott SD, Halperin JL, Waldo AL, Ezekowitz MD, Weitz JI, Špinar J, Ruzyllo W, Ruda M, Koretsune Y, Betcher J, Shi M, Grip LT, Patel SP, Patel I, Hanyok JJ, Mercuri M, Antman EM ; ENGAGE AF-TIMI 48 Investigators : Edoxaban versus warfarin in patients with atrial fibrillation. $N$ Engl J Med 369: 2093-2104, 2013.

8) Gorelick PB, Wong KS, Bae HJ, Pandey DK : Large artery intracranial occlusive disease : a large worldwide burden but a relatively neglected frontier. Stroke $\quad 39: 2396-2399$, 2008.

9) Granger CB, Alexander JH, McMurray JJ, Lopes RD, Hylek EM, Hanna M, Al-Khalidi HR, Ansell J, Atar D, Avezum A, Bahit MC, Diaz R, Easton JD, Ezekowitz JA, Flaker G, Garcia D, Geraldes M, Gersh BJ, Golitsyn S, Goto S, Hermosillo AG, Hohnloser SH, Horowitz J, Mohan P, Jansky P, Lewis BS, Lopez-Sendon JL, Pais P, Parkhomenko A, Verheugt FW, Zhu J, Wallentin L; ARISTOTLE Committees and Investigators: Apixaban versus warfarin in patients with atrial fibrillation. N Engl J Med $365:$ 981-992, 2011.

10) Holmstedt CA, Turan TN, Chimowitz MI: Atherosclerotic intracranial arterial stenosis : risk factors, diagnosis, and 
treatment. Lancet Neurol 12: 1106-1114, 2012.

11) Kasner SE, Chimowitz MI, Lynn MJ, Howlett-Smith H, Stern BJ, Hertzberg VS, Frankel MR, Levine SR, Chaturvedi S, Benesch CG, Sila CA, Jovin TG, Romano JG, Cloft HJ ; Warfarin Aspirin Symptomatic Intracranial Disease Trial Investigators : Predictors of ischemic stroke in the territory of a symptomatic intracranial arterial stenosis. Circulation 113: 555-563, 2006.

12) Ma Y, Yang F, Jiao L, Li M, Wang Y, Chen Y, Ling F : Superficial temporal artery-middle cerebral artery bypass surgery for refractory symptomatic intracranial atherosclerotic stenosis. World Neurosurg 104: 74-81, 2017.

13) Miao Z, Zhang Y, Shuai J, Jiang C, Zhu Q, Chen K, Liu L, Li B, Shi X, Gao L, Liu Y, Wang F, Li Y, Liu T, Zheng H, Wang Y, Wang Y ; Study Group of Registry Study of Stenting for Symptomatic Intracranial Artery Stenosis in China: Thirtyday outcome of a multicenter registry study of stenting for symptomatic intracranial artery stenosis in China. Stroke 46: 2822-2829, 2015.

14) Miyawaki S, Imai $H$, Takayanagi S, Mukasa A, Nakatomi H, Saito N : Identification of a genetic variant common to moyamoya disease and intracranial major artery stenosis/occlusion. Stroke $\quad 43: 3371-3374,2012$.
15) Mori T, Fukuoka M, Kazita K, Mori K : Follow-up study after intracranial percutaneous transluminal cerebral balloon angioplasty. AJNR Am J Neuroradiol 19 : 1525-1533, 1998.

16) Patel MR, Mahaffey KW, Garg J, Pan G, Singer DE, Hacke W, Breithardt G, Halperin JL, Hankey GJ, Piccini JP, Becker RC, Nessel CC, Paolini JF, Berkowitz SD, Fox KA, Califf $\mathrm{RM}$; ROCKET AF Investigators : Rivaroxaban versus warfarin in nonvalvular atrial fibrillation. $N$ Engl J Med $\mathbf{3 6 5}$ : 883-891, 2011.

17) Suh DC, Kim JK, Choi JW, Choi BS, Pyun HW, Choi YJ, Kim MH, Yang HR, Ha HI, Kim SJ, Lee DH, Choi CG, Hahm $\mathrm{KD}$, Kim JS : Intracranial stenting of severe symptomatic intracranial stenosis : results of 100 consecutive patients. AJNR Am J Neuroradiol 29: 781-785, 2008.

18) Zaidat OO, Fitzsimmons BF, Woodward BK, Wang Z, KillerOberpfalzer M, Wakhloo A, Gupta R, Kirshner H, Megerian JT, Lesko J, Pitzer P, Ramos J, Castonguay AC, Barnwell S, Smith WS, Gress DR ; VISSIT Trial Investigators : Effect of a balloon-expandable intracranial stent vs medical therapy on risk of stroke in patients with symptomatic intracranial stenosis : the VISSIT randomized clinical trial. JAMA 313: 1240-1248, 2015.

目的：これまでの臨床試験の結果, 症候性頭蓋内動脈狭窄症においては血管内治療や外科的治療の 有効性が示されていない. しかし内科的治療抵抗性患者も少なくなく，このような症例をどう治療す るかについては一定の見解がない. 本稿では, 本疾患について概観し, 治療選択について考察する.

背景 : 頭蓋内動脈狭窄症はわが国の全脳梗塞の原因の約 30\%を占めるとされており, 症候性高度狭 窄例（狭窄度 $70 \%$ 以上）の脳卒中再発率はアスピリン投与下で年間 $23 \%$, 積極的内科治療（抗血小 板療法, 降圧, 脂質低下療法, 禁煙などの生活習慣改善）を受けても年間 $12 \%$ 超えると報告されて いる.

各治療法とエビデンス：(1)内科的治療：症候性頭蓋内動脈狭窄症に対する内科的治療に関するラン ダム化比較試験においてはワルファリンよりもアスピリンが優位であることが示された. (2)血管内治 療：2 つのランダム化比較試験において血管内治療の有効性は示されなかった．現在これらの試験で 明らかとなったリスク因子を考慮に入れた新たな試験が開始されている. (3)外科的治療（バイパス手 術）：頭蓋内動脈狭窄症のみを対象としたバイパス手術の有効性を検討した臨床試験は存在しない. このため有効性は不明であるが, 他治療に抵抗性, あるいは適しない患者に治療が実施されている.

結語：頭蓋内動脈狭窄症に対する標準治療は内科的治療であるが, その抵抗例, 非適応例において は介入治療が有効な可能性があり, 今後の臨床試験で確認されていくものと考えられる. 